\title{
Characterization of human liver thermostable phenol sulfotransferase (SULT1A1) allozymes with 3,3',5-triiodothyronine as the substrate
}

\author{
X Li, D L Clemens ${ }^{1}$, J R Cole ${ }^{1}$ and R J Anderson ${ }^{2}$ \\ Creighton University School of Medicine, Omaha, Nebraska 68105, USA \\ ${ }^{1}$ University of Nebraska Medical Center and VA Medical Center, Omaha, Nebraska 68105, USA \\ ${ }^{2}$ Creighton University School of Medicine and VA Medical Center, Omaha, Nebraska 68105, USA \\ (Requests for offprints should be addressed to R J Anderson, VAMC, 4101 Woolworth Ave., Research 151, Omaha, Nebraska 68105, USA; \\ Email: robert.anderson4@med.va.gov)
}

\begin{abstract}
Sulfotransferase 1A1 (SULT1A1) (thermostable phenol sulfotransferase, TS PST1, P-PST) is important in the metabolism of thyroid hormones. SULT1A1 isolated from human platelets displays wide individual variations not only in the levels of activity, but also in thermal stability. The activity of the allelic variant or allozyme SULT1A1*1, which possesses an arginine at amino acid position 213 (Arg213) has been shown to be more thermostable than the activity of the SULT1A1*2 allozyme which possesses a histidine at this position (His213) when using $p$-nitrophenol as the substrate. We isolated a SULT1A $1 * 1$ cDNA from a human liver cDNA library and expressed both SULT1A1*1 and SULT1A1*2 in eukaryotic cells. The allozymes were assayed using iodothyronines as the substrates and their biochemical properties were compared. SULT1A1*1 activity was more thermostable and more sensitive to $\mathrm{NaCl}$ than was
\end{abstract}

SULT1A1*2 activity when assayed with 3,5,3'triiodothyronine $\left(\mathrm{T}_{3}\right)$. Sensitivities to 2,6-dichloro-4nitrophenol (DCNP) and apparent $K_{\mathrm{m}}$ values for SULT1A1*1 and for SULT1A1*2 with iodothyronines were similar. Based on $K_{\mathrm{m}}$ values, the preferences of these SULT1A1 allozymes for iodothyronine substrates were the same $\left(3,3^{\prime}\right.$-diiodothyronine $\left(3,3^{\prime}-T_{2}\right)>3^{\prime}$, $5^{\prime}, 3$-triiodothyronine $\left(\mathrm{rT}_{3}\right)>\mathrm{T}_{3}>$ thyroxine $\left(\mathrm{T}_{4}\right)>>3,5-$ diiodothyronine $\left.\left(3,5-\mathrm{T}_{2}\right)\right)$. SULT1A1*1 activity was significantly higher than the SULT1A1*2 activity with $\mathrm{T}_{3}$ as the substrate. Potential differences in thyroid hormone sulfation between individuals with predominant SULT1A1*1 versus SULT1A1*2 allozymes are most likely due to differences in catalytic activity rather than substrate specifity.

Journal of Endocrinology (2001) 171, 525-532

\section{Introduction}

Sulfation contributes to the inactivation of $3,5,3^{\prime}$ triiodothyronine $\left(\mathrm{T}_{3}\right)$ and other iodothyronines by the addition of a sulfuryl moiety to the $4^{\prime}$-hydroxyl group. 3'-Phosphoadenosine-5'-phosphosulfate (PAPS) donates the sulfuryl group in the reaction. $\mathrm{T}_{3}$ sulfate $\left(\mathrm{T}_{3} \mathrm{~S}\right)$ is a major product of human $\mathrm{T}_{3}$ metabolism (Chopra et al. 1992, LoPresti \& Nicoloff 1994). $T_{3} S$ is a better substrate than $\mathrm{T}_{3}$ for type I $5^{\prime}$-deiodinase $\left(5^{\prime} \mathrm{DI}\right)$, and this results in enhancement of deiodination. Several human sulfotransferases (SULTs) are capable of sulfating thyroid hormones. These include SULT1A1 (thermostable phenol SULT, TS PST1, P-PST) (Young et al. 1988, Anderson et al. 1995, Kester et al. 1999a), SULT1A3 (TL PST, M-PST) (Young et al. 1988, Kester et al. 1999a), SULT1B1 (Fujita et al. 1997, Wang et al. 1998), SULT1C1 (Li et al. 2000), SULT1E1 (EST) (Li \& Anderson 1999, Kester et al. 1999b), and SULT2A1 (DHEA ST) (Li \& Anderson 1999). Endogenous human liver SULT1A1 has been shown to sulfate $\mathrm{T}_{3}$ and other thyroid hormones (Young et al. 1988, Anderson et al. 1995, Kester et al. 1999a), but there have not been detailed characterizations of the biochemical properties of recombinant human liver SULT1A1 with iodothyronines as the substrates.

An added complexity in the understanding of sulfation of thyroid hormone by SULT1A1 is the occurrence of SULT1A1 allozymes (allelic variants that result in amino acid changes in the enzyme). There are at least seven known SULT1A1 allozymes (Wilborn et al. 1993, Zhu et al. 1993, Hwang et al. 1995, Jones et al. 1995, Ozawa et al. 1995, Raftogianis et al. 1997, 1999). It is not clear whether these allozymes have different specificities for iodothyronines.

SULT1A1 from the human platelet displayed wide individual variations, not only in the level of activity, but 
Table 1 Comparison of amino acids among SULT1A1 allozymes

\begin{tabular}{|c|c|c|c|c|c|c|c|c|c|c|}
\hline & AA37 & AA213 & AA223 & AA90 & AA243 & AA282 & AA290 & AA146 & AA181 & References \\
\hline \multicolumn{11}{|l|}{ Allozyme } \\
\hline SULT1A $1 * 1$ & Arg & Arg & Met & Pro & Val & Glu & Ser & Ala & Glu & Ozawa et al. (1995); Clemens et al. (1996) \\
\hline SULT1A $1 * 2$ & Arg & His & Met & Pro & Val & Glu & Ser & Ala & Glu & Zhu et al. (1993) \\
\hline SULT1A $1 * 4$ & GIn & Arg & Met & Pro & Val & Glu & Ser & Ala & Glu & Raftogianis et al. (1997, 1999) \\
\hline SULT1A $1 * 5$ & $\operatorname{Arg}$ & Arg & Met & Leu & Ala & Glu & Ser & Ala & Glu & Hwang et al. (1995) \\
\hline SULT1A $1 * 6$ & Arg & Arg & Met & Pro & Val & Lys & Thr & Ala & Glu & Wilborn et al. (1993) \\
\hline
\end{tabular}

Residues in bold and italic are different amino acids (AA) when compared with SULT1A1*1.

also in thermal stability (Van Loon \& Weinshilboum 1984, Price et al. 1989, Anderson \& Liebentritt 1990). Segregation analysis of data from family studies showed human platelet SULT1A1 activity and individual variations in its thermal stability were controlled by genetic polymorphisms (Price et al. 1989). The most common SULT1A1 allozyme is SULT1A1*1, a variant with the amino acid arginine (Arg) at position 213 (0.67 gene frequency) (Ozawa et al. 1995, Raftogianis et al. 1997, 1999). The second most common SULT1A1 allozyme is SULT1A1*2 (His213, 0.31 gene frequency) (Zhu et al. 1993, Raftogianis et al. 1997, 1999). SULT1A1^1 (Arg213) and SULT1A1*2 (His213) allozymes have been reported in Caucasians, Asians and Africans (Raftogianis et al. 1997, Coughtrie et al. 1999, Ozawa et al. 1999). Isolation of cDNAs of the SULT1A1*1 and SULT1A1*2 allozymes was accomplished by cloning and sequencing DNA from leukocytes and livers of individuals identified by specific human platelet SULT1A1 phenotypes. Individuals homozygous for SULT1A1*2 allozyme (His/His213) showed phenotypes of lower thermal stability and lower activity, when the enzyme was assayed with $p$-nitrophenol, than did individuals homozygous for SULT1A1*1 allozyme (Arg/Arg213) (Raftogianis et al. 1997). Individual differences in thyroid hormone metabolism occur, and a difference in substrate specificity or enzyme activity of SULT1A1 allozymes might contribute to these differences.

Using bacterially expressed SULT1A1 allozymes isolated from human liver, Ozawa et al. (1999) showed that SULT1A1*1 was more thermostable than SULT1A1*2. However, contrary to results with platelet samples, the differences in activities with recombinant enzymes were minimal when assayed with $4 \mu \mathrm{M} p$-nitrophenol (Ozawa et al. 1999). On the other hand, it was recently reported that recombinant SULT1A1 allozymes had very different effects on activation of promutagens (Glatt et al. 2000). Another group tested SULT1A1 allozymes that contained the common Arg213 and His213 changes and found different specificities for 3,3'-diiodothyronine $\left(3,3^{\prime}-\mathrm{T}_{2}\right)$ (Visser et al. 1996). However, the proteins expressed from the cDNAs that were used also had amino acid changes at positions 282 (Glu $\rightarrow$ Lys) and 290 (Ser $\rightarrow \mathrm{Thr}$ ) for the Arg213 variant and at positions 146 (Ala $\rightarrow$ Thr) and 181 (Glu $\rightarrow$ Gly) for the His213 variant (Wilborn et al. 1993, Jones et al. 1995, Visser et al. 1996; see Table 1).

We were interested in determining whether there were differences in apparent $K_{\mathrm{m}}$ values, biochemical properties and activities of the two most common SULT1A1 allozymes when iodothyronines were used as the substrates. Identification of differences might make it possible to predict individual responses to iodothyronines based upon the presence of distinct SULT1A1 allozymes. In this report, we demonstrated that the common polymorphisms of human liver SULT1A1*1 and SULT1A1*2 expressed in COS-1 cells catalyzed the sulfation of $\mathrm{T}_{3}$ and other iodothyronines. We also characterized common biochemical properties of these allozymes with $\mathrm{T}_{3}$ as the substrate, and determined their preferences for $\mathrm{T}_{3}, 3,3^{\prime}, 5,5^{\prime}-$ tetraiodothyronine $\left(\mathrm{T}_{4}\right), 3^{\prime}, 5^{\prime}, 3^{\prime}$-triiodothyronine $\left(\mathrm{rT}_{3}\right)$, $3,3^{\prime}$-diiodothyronine $\left(3,3^{\prime}-\mathrm{T}_{2}\right)$ and 3,5-diiodothyronine $\left(3,5-\mathrm{T}_{2}\right)$.

\section{Materials and Methods}

\section{Materials}

COS-1 cells were obtained from the American Type Culture Collection (ATCC), Rockville, MD, USA. $\left[{ }^{35} \mathrm{~S}\right] 3^{\prime}$-Phosphoadenosine- $5^{\prime}$-phosphosulfate $\left(\left[{ }^{35} \mathrm{~S}\right] \mathrm{PAPS}\right.$, specific activity from 1.52 to $2.50 \mathrm{Ci} / \mathrm{mmol}$ ) was purchased from New England Nuclear (NEN) Dupont, Boston, MA, USA. 3,3'-Diiodothyronine $\left(3,3^{\prime}-\mathrm{T}_{2}\right)$ was a gift from Dr S-Y Wu (Long Beach, CA, USA). 3,3',5-Triiodothyronine $\left(\mathrm{T}_{3}\right), \quad 3^{\prime}, 5^{\prime}, 3$-triiodothyronine $\left(\mathrm{rT}_{3}\right), \quad 3,3^{\prime}, 5,5^{\prime}$-tetraiodothyronine $\left(\mathrm{T}_{4}\right), \quad 3,5$-diiodothyronine $\left(3,5-\mathrm{T}_{2}\right), 2,6$-dichloro-4-nitrophenol (DCNP), $p$-nitrophenol, $o$-nitrophenol- $\beta$-D-galactopyranoside (ONPG) and ecteola cellulose (fine mesh) were purchased from Sigma, St Louis, MO, USA. Dithiothreitol (DTT) was purchased from CalBiochem, La Jolla, CA, USA. Lipofectamine was obtained from Gibco, Grand Island, 
NY, USA. The SULT1A1*2 cDNA was a gift from Dr M E McManus (Queensland, Australia) (Zhu et al. 1993).

\section{Isolation of SULT1A1*1 cDNAs}

Human SULT1A1*1 cDNAs were isolated from a $\lambda$ UniZAP XR human liver cDNA library (Stratagene, La Jolla, CA, USA). Briefly, phage were plated at $25000 \mathrm{pfu} /$ plate on Escherichia coli XL1-Blue. Plaques were transferred to Hybond-N (Amersham, Arlington Heights, IL, USA) membranes and hybridized to a ${ }^{32} \mathrm{P}-$ labeled fragment of a SULT1A1 cDNA (Zhu et al. 1993). Twenty positive plaques were identified and subjected to two additional rounds of plaque purification. Bluescript phagemids were rescued from the $\lambda$ Uni-ZAP vector by coinfection of infected cultures with ExAssit helper phage and propagated as double stranded phagemids in E. coli SOLR. The recombinant Bluescript phagemids were isolated by alkaline lysis (Ish-Horowicz \& Burke 1981) and initially analyzed by digestion with EcoRI and XhoI to determine the size of the inserts. Three different sizes of inserts were observed and one representative clone from each size class was subcloned into pSP72 (Promega, Madison, WI, USA), transformed into E. coli $\mathrm{DH} 5 \alpha$ and further analyzed by restriction and sequence analysis. Sequence analysis was performed on both strands by the dideoxy method (Sanger et al. 1977) using the Sequenase version 2 kit (USB, Cleveland, OH, USA).

\section{Construction of expression vectors}

In order to express the SULT1A1*1 in eukaryotic cells, SULT1A1*1 cDNA was inserted into the EcoRI and EcoRV sites of the eukaryotic expression vector pcDNA3 (Invitrogen, Carlsbad, CA, USA). The SULT1A1*2 cDNA was also inserted into the pcDNA3 vector.

\section{Expression of SULT1A1*1 and SULT1A1*2}

Human SULT1A1*1 and SULT1A1*2 were expressed in COS-1 cells by transfection using lipofectamine as previously described (Li \& Anderson 1999), and the cells were harvested three days later. The high speed supernatants were prepared as described previously (Li \& Anderson 1999). Protein was determined by the method of Bradford (1976) with BSA as the standard. In order to normalize for the transfection efficiency, $2 \cdot 25 \mu \mathrm{g}$ DNA of pCH110 (Pharmacia, Piscataway, NJ, USA) were co-transfected with $22.5 \mu \mathrm{g}$ plasmid containing SULT1A1 allozyme/ $75 \mathrm{~cm}^{2}$ flask.

\section{Sulfotransferase assays}

SULT activity was measured by the method of Young et al. (1988) as modified by Li and Anderson (1999). The enzyme assay was performed at optimal conditions with $\mathrm{T}_{3}$ as the substrate and $0 \cdot 4 \mu \mathrm{M}{ }^{35} \mathrm{~S}$-PAPS as the co-substrate. SULT1A1*1 preparations of $23 \cdot 25 \mu \mathrm{g}$ and SULT1A1*2 preparations of $19 \cdot 4 \mu \mathrm{g}$ of high speed supernatant protein were used in all assays. Samples were incubated for $15 \mathrm{~min}$, and $60 \mathrm{mM}$ potassium phosphate buffer, $\mathrm{pH} 7 \cdot 0$ was used. The SULT assay with $p$-nitrophenol as the substrate was carried out by the method of Anderson and Liebentritt (1990). Mock transfected COS-1 cells (no cDNA) served as controls for each assay. Net activities were calculated by subtraction of the activities/mg protein in mock transfected cells from the activities/mg protein detected in the transfected cells. This accounted for the potential effect of endogenous SULT activities. Net SULT activities were expressed as Units/mg protein. One Unit of enzyme activity represents one nmol of sulfated product formed per hour at $37^{\circ} \mathrm{C}$. Thermal stability was tested by the methods of Reiter et al. (1983) as modified by Anderson et al. (1988).

\section{$\beta$-Galactosidase quantitation}

$\beta$-Galactosidase activity was determined as described by Clemens and Carlson (1989). Briefly, high speed supernatant $(50 \mu \mathrm{l})$ was added to $350 \mu \mathrm{l} \mathrm{Z}$ buffer $(60 \mathrm{mM}$ $\mathrm{Na}_{2} \mathrm{HPO}_{4}, 40 \mathrm{mM} \mathrm{NaH} \mathrm{PO}_{4} \cdot \mathrm{H}_{2} \mathrm{O}, 10 \mathrm{mM} \mathrm{KCl}, 1 \mathrm{mM}$ $\mathrm{MgSO}_{4}, 50 \mathrm{mM}$ 2-mercaptoethanol), $\mathrm{pH} 7 \cdot 0$ and $80 \mu \mathrm{l}$ ONPG $(4 \mathrm{mg} / \mathrm{ml})$ in $0 \cdot 1 \mathrm{M}$ potassium phosphate buffer, $\mathrm{pH} 7 \cdot 5$. The reaction was incubated at $30^{\circ} \mathrm{C}$ for $10 \mathrm{~min}$. The reaction was stopped by addition of $200 \mu \mathrm{l}$ of $1 \mathrm{M}$ $\mathrm{Na}_{2} \mathrm{CO}_{3}$ at $\mathrm{pH}$ 11. $\beta$-Galactosidase activity was determined spectrophotometrically at $420 \mathrm{~nm}$.

\section{Data analysis}

Apparent $K_{\mathrm{m}}$ and $\mathrm{V}_{\max }$ values were calculated by the direct linear plot method (Eisenthal \& Cornish-Bowden 1974) using the Enzpack 3 program by Williams (ElsevierBiosoft, Cambridge, UK). Kinetic data were presented in double reciprocal plots using the $K_{\mathrm{m}}$ values obtained by the direct linear plot method. The 50\% inactivation temperatures $\left(\mathrm{T}_{50}\right)$ and $50 \%$ inhibitory concentrations $\left(\mathrm{IC}_{50}\right)$ with DCNP and $\mathrm{NaCl}$ were determined using a curve-fitting program (GraphPad Software, San Diego, CA, USA). Statistical significance was analyzed by Student's $t$-test.

\section{Results and Discussion}

\section{Isolation and molecular characterization of SULT1A1*1} clones

Initially 250000 plaques were screened; 10 of these were positive. The positive isolates were plaque purified twice more prior to the rescue of phagemids. The phagemids rescued from the positive bacteriophage were digested with EcoRI and XhoI to determine the size of the inserts. 
1 ATGGAGCTG ATC CAGGAC ACC TCC CGC CCGCCACTG GAGTAC GTGAAGGGGGTC CCGCTC

$\begin{array}{llllllllllllllllllll}\text { M } & \text { E } & \text { L } & \text { I } & \text { Q } & \text { D } & \text { T } & \text { S } & \text { R } & \text { P } & \text { P } & \text { L } & \text { E } & \text { Y } & \text { V } & \text { K } & \text { G } & \text { V } & \text { P } & \text { L }\end{array}$

61 ATC AAGTAC TTT GCAGAGGCACTGGGGCCC CTGCAGAGCTTC CAGGCC CGGCCT GAT GAC $\begin{array}{llllllllllllllllllll}\text { I } & \text { K } & \text { Y } & \text { F } & \text { A } & \text { E } & \text { A } & \text { L } & \text { G } & \text { P } & \text { L } & \text { Q } & \text { S } & \text { F } & \text { Q } & \text { A } & \text { R } & \text { P } & \text { D } & \text { D }\end{array}$

121 CTG CTC ATC AGC ACC TAC CCC AAGTCC GGC ACT ACC TGGGTA AGCCAGATT CTG GACATG $\begin{array}{llllllllllllllllllll}\mathrm{L} & \mathrm{L} & \mathrm{I} & \mathrm{S} & \mathrm{T} & \mathrm{Y} & \mathrm{P} & \mathrm{K} & \mathrm{S} & \mathrm{G} & \mathrm{T} & \mathrm{T} & \mathrm{W} & \mathrm{V} & \mathrm{S} & \mathrm{Q} & \mathrm{I} & \mathrm{L} & \mathrm{D} & \mathbf{M}\end{array}$

181 ATC TAC CAGGGTGGTGACCTG GAGAAGTGT CAC CGAGCT CCC ATC TTC ATG CGGGTGCCC $\begin{array}{llllllllllllllllllll}\text { I } & \mathrm{Y} & \mathrm{Q} & \mathrm{G} & \mathrm{G} & \mathrm{D} & \mathrm{L} & \mathrm{E} & \mathrm{K} & \mathrm{C} & \mathrm{H} & \mathrm{R} & \mathrm{A} & \mathrm{P} & \mathrm{I} & \mathrm{F} & \mathrm{M} & \mathrm{R} & \mathrm{V} & \mathrm{P}\end{array}$

241 TTC CTT GAGTTC AAAGCC CCAGGGATT CCC TCA GGGATGGAGACT CTG AAAGAC ACACCG

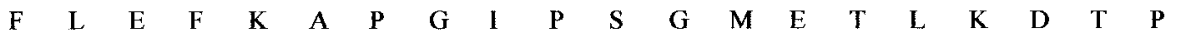

301 GCC CCACGACTC CTG AAGACACAC CTG CCC CTG GCT CTG CTC CCC CAGACT CTG TTG GAT $\begin{array}{llllllllllllllllllll}\text { A } & \mathbf{P} & \mathbf{R} & \mathrm{L} & \mathrm{L} & \mathrm{K} & \mathrm{T} & \mathrm{H} & \mathrm{L} & \mathrm{P} & \mathrm{L} & \mathrm{A} & \mathrm{L} & \mathrm{L} & \mathrm{P} & \mathrm{Q} & \mathrm{T} & \mathrm{L} & \mathrm{L} & \mathrm{D}\end{array}$

361 CAGAAGGTC AAGGTGGTC TAT GTT GCC CGC AAC GCAAAGGAT GTGGCAGTT TCC TAC TAC $\begin{array}{llllllllllllllllllll}\mathbf{Q} & \mathrm{K} & \mathrm{V} & \mathrm{K} & \mathrm{V} & \mathrm{V} & \mathrm{Y} & \mathrm{V} & \mathbf{A} & \mathbf{R} & \mathrm{N} & \mathbf{A} & \mathrm{K} & \mathbf{D} & \mathrm{V} & \mathbf{A} & \mathrm{V} & \mathrm{S} & \mathrm{Y} & \mathrm{Y}\end{array}$

421 CAC TTC TAC CAC ATG GCC AAGGTGCAC CCT GAGCCT GGGACC TGGGAC AGC TTC CTGGAG $\begin{array}{llllllllllllllllllll}\text { H } & \text { F } & \text { Y } & \text { H } & \text { M } & \text { A } & \text { K } & \text { V } & \text { H } & \text { P } & \text { E } & \text { P } & \text { G } & \text { T } & \text { W } & \text { D } & \text { S } & \text { F } & \text { L } & \text { E }\end{array}$

481 AAGTTC ATG GTC GGAGAAGTG TCC TAC GGATCC TGGTAC CAGCAC GTGCAGGAGTGGTGG $\begin{array}{llllllllllllllllllll}\text { K } & \text { F } & \text { M } & \text { V } & \text { G } & \text { E } & \text { V } & \text { S } & \text { Y } & \text { G } & \text { S } & \text { W } & \text { Y } & \text { Q } & \text { H } & \text { V } & \text { Q } & \text { E } & \text { W } & \text { W }\end{array}$

541 GAGCTG AGCCGC ACC CACCCT GTT CTC TAC CTC TTC TAT GAAGACATGAAGGAGAACCCG $\begin{array}{llllllllllllllllllll}\mathrm{E} & \mathrm{L} & \mathrm{S} & \mathrm{R} & \mathrm{T} & \mathrm{H} & \mathrm{P} & \mathrm{V} & \mathrm{L} & \mathrm{Y} & \mathrm{L} & \mathrm{F} & \mathrm{Y} & \mathrm{E} & \mathrm{D} & \mathrm{M} & \mathrm{K} & \mathrm{E} & \mathrm{N} & \mathrm{P}\end{array}$

601 AAAAGGGAGATT CAAAAGATC CTGGAGTTT GTGGGGCGC TCC CTG CCAGAGGAGACC GTG $\begin{array}{llllllllllllllllllll}K & R & E & I & Q & K & I & L & E & F & V & G & R & S & L & P & E & E & T & V\end{array}$

661 GACTTC ATG GTT CAGCAC ACGTCG TTC AAGGAGATGAAGAAGAACCCT ATG ACC AACTAC $\begin{array}{llllllllllllllllllll}\mathrm{D} & \mathrm{F} & \mathrm{M} & \mathrm{V} & \mathrm{Q} & \mathrm{H} & \mathrm{T} & \mathrm{S} & \mathrm{F} & \mathrm{K} & \mathrm{E} & \mathrm{M} & \mathrm{K} & \mathrm{K} & \mathrm{N} & \mathrm{P} & \mathrm{M} & \mathrm{T} & \mathrm{N} & \mathrm{Y}\end{array}$

721 ACC ACC GTC CCC CAGGAGTTC ATGGACCAC AGCATC TCC CCC TTC ATG AGGAAAGGCATG $\begin{array}{llllllllllllllllllll}\mathrm{T} & \mathrm{T} & \mathrm{V} & \mathrm{P} & \mathrm{Q} & \mathrm{E} & \mathrm{F} & \mathrm{M} & \mathrm{D} & \mathrm{H} & \mathrm{S} & \mathbf{I} & \mathrm{S} & \mathrm{P} & \mathrm{F} & \mathrm{M} & \mathrm{R} & \mathrm{K} & \mathrm{G} & \mathrm{M}\end{array}$

801 GCT GGGGAC TGGAAGACC ACC TTC ACC GTGGCGCAGAAT GAGCGC TTC GAT GCGGACTAT $\begin{array}{llllllllllllllllllll}\text { A } & G & \text { D } & \text { W } & \text { K } & \text { T } & \text { T } & \text { F } & \text { T } & \text { V } & \text { A } & \text { Q } & \text { N } & \text { E } & \text { R } & \text { F } & \text { D } & \text { A } & \text { D } & \text { Y }\end{array}$

861 GCGGAGAAGATG GCAGGCTGC AGCCTC AGC TTC CGC TCT GAGCTG TGA $\begin{array}{llllllllllllllll}\text { A } & \text { E } & \text { K } & \text { M } & \text { A } & \text { G } & \text { C } & \text { S } & \text { L } & \text { S } & \text { F } & \text { R } & \text { S } & \text { E } & \text { L } & *\end{array}$

Figure 1 The open reading frame and the amino acid sequence of SULT1A1*1 (the position of Arg213 is shown as the letter within a box). The amino acid sequence of SULT1A1*2 (His213) contains a histidine at amino acid 213.

All of the isolates appeared to contain inserts of approximately $1200 \mathrm{bp}$, which was in close agreement with previously isolated clones (Wilborn et al. 1993, Zhu et al. 1993, Hwang et al. 1995, Jones et al. 1995). Further restriction enzyme analysis indicated variations in the inserts, which fell into three classes. One representative of each class was chosen for further detailed analysis. Sequence analysis of these three clones revealed that the only differences were located outside of the putative coding regions in the $3^{\prime}$ and $5^{\prime}$ untranslated regions. Each of the clones contained an identical open reading frame of 885 bp (Fig. 1). This open reading frame was predicted to encode a protein of 295 amino acids with a molecular mass of approximately $34 \mathrm{kDa}$, which is in close agreement with the previously reported apparent molecular mass of SULT1A1 (Wilborn et al. 1993).

At least 7 allozymes from 18 allelic variants of SULT1A1 have previously been reported (Wilborn et al. 1993, Zhu et al. 1993, Hwang et al. 1995, Jones et al. 1995, Ozawa et al. 1995, Raftogianis et al. 1997, 1999). A comparison of these with the predicted amino acid sequence of our isolate showed that they were all very similar, and that our isolated cDNA was identical to that reported by Ozawa et al. (1995; Genbank accession no.: 

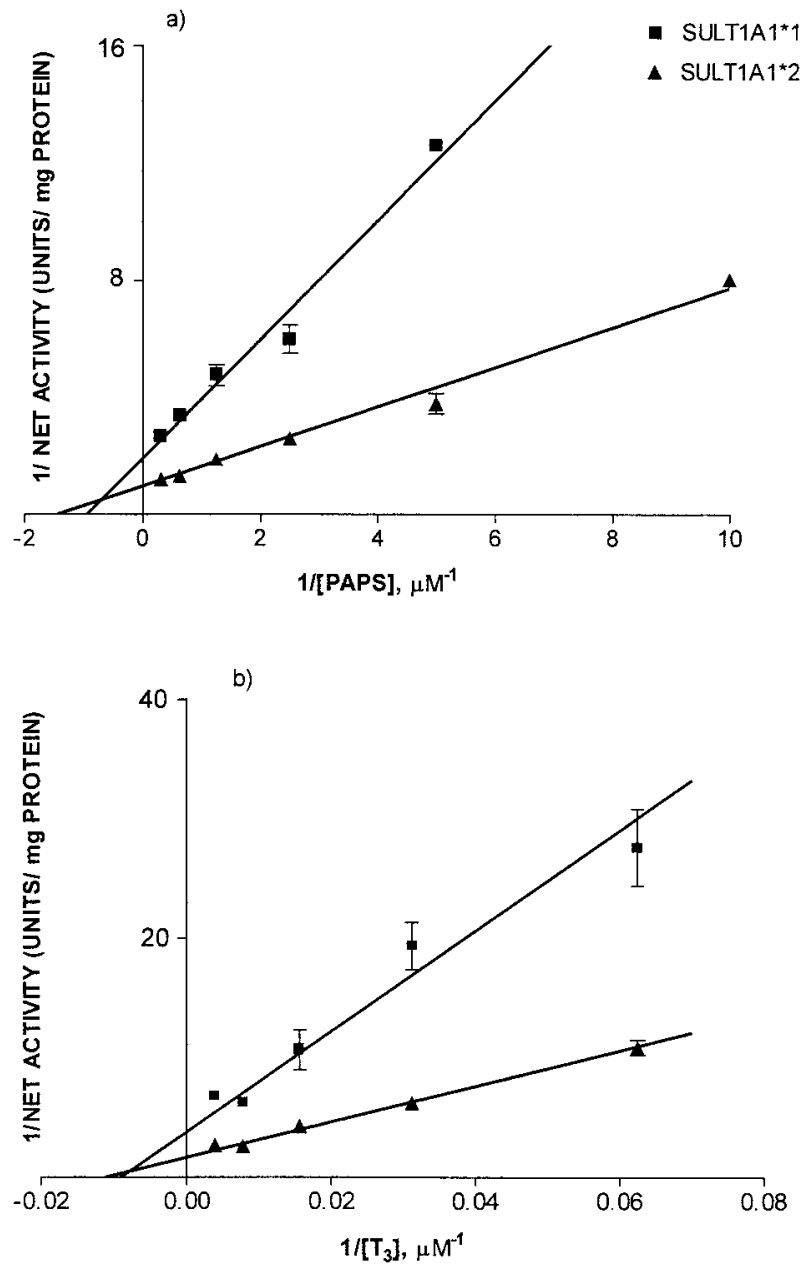

Figure 2 Kinetic analyses of SULT1A $1 * 1$ and SULT1A $1 * 2$ activities with the co-substrates PAPS and $T_{3}$. (a) Double reciprocal plot of SULT1A $1 * 1$ and SULT1A $1 * 2$ with PAPS as the variable substrate and $150 \mu \mathrm{M} \mathrm{T}_{3}$ as the constant substrate. Each point represents the mean \pm S.E.M. of 3 determinations from a representative experiment. (b) Double reciprocal plot of SULT1A ${ }^{*} 1$ and SULT1A $1 * 2$ with $T_{3}$ as the variable substrate and $0.4 \mu \mathrm{M}$ PAPS as the constant substrate. Each point represents the mean \pm S.E.M. of 3 determinations from a representative experiment.
X78283). The differences from the predicted amino acid sequences reported by others are listed in Table 1 . Allozyme designations $1 * 5,1 * 6$ and $1 * 7$ have been adopted for ease of identification.

\section{Expressed SULT1A1 allozyme biochemical properties}

$\boldsymbol{K}_{\mathbf{m}}$ and $\mathbf{V}_{\max }$ Initially, sulfotransferase assays for the two allozymes were performed with $150 \mu \mathrm{M} \mathrm{T}$ and different concentrations of $\left[{ }^{35} \mathrm{~S}\right] \mathrm{PAPS}$. The apparent $K_{\mathrm{m}}$ values with $\left[{ }^{35}\right.$ S]PAPS were $1.06 \mu \mathrm{M}$ for SULT1A1*1 and $0 \cdot 70 \mu \mathrm{M}$ for SULT1A1*2 (Fig. $2 \mathrm{a}$ ). The values with PAPS were similar to the results obtained by other groups: $0.65 \mu \mathrm{M}$ with $\mathrm{T}_{3}$ from Kester et al. (1999a), and 1.21 $\mu \mathrm{M}$ with $p$-nitrophenol from Raftogianis et al. (1999) for SULT1A1*1, and 0.98 $\mu \mathrm{M}$ from Raftogianis et al. (1999) for SULT1A1*2. Apparent $K_{\mathrm{m}}$ values were determined by using $\mathrm{T}_{3}$ in concentrations ranging from 1 to $256 \mu \mathrm{M}$. No activity was detected consistently below $8 \mu \mathrm{M} \mathrm{T} \mathrm{T}_{3}$. Apparent $K_{\mathrm{m}}$ values were $84 \cdot 4 \pm 5 \cdot 5 \mu \mathrm{M}$ for SULT1A1*1 and $101 \cdot 3 \pm 5 \cdot 7 \mu \mathrm{M}$ for SULT1A1*2 (mean \pm s.E.M., $n=3$ experiments, $P=0 \cdot 10$; Fig. $2 b$ ). These values were similar to each other and to the results obtained by other groups using partially purified SULT1A1 from pooled cytosol preparations of human liver (Young et al. 1988, Kester et al. 1999a). The data supported the conclusion that SULT1A1 expressed in COS-1 cells was similar to the endogenous human liver SULT1A1.

We next investigated the ability of these allozymes to use other iodothyronines as substrates. Apparent $K_{\mathrm{m}}$ values for SULT1A1*1 with iodothyronines were: $3,3^{\prime}-\mathrm{T}_{2}$, $0.63 \mu \mathrm{M} ; \mathrm{rT}_{3}, 36 \cdot 1 \mu \mathrm{M}$; and $\mathrm{T}_{4}, 126 \mu \mathrm{M}$. Apparent $K_{\mathrm{m}}$ values for SULT1A1*2 with iodothyronines were: 3,3'$\mathrm{T}_{2}, 0.51 \mu \mathrm{M} ; \mathrm{rT}_{3}, 49.8 \mu \mathrm{M}$; and $\mathrm{T}_{4}, 208 \mu \mathrm{M}$ (Table 2). The $K_{\mathrm{m}}$ values with each substrate were similar for the two allozymes.

To compare the $\mathrm{V}_{\max }$ values of expressed SULT1A1*1 and SULT1A1*2 activities, we normalized transfection efficiency by $\beta$-galactosidase quantitation. The $V_{\max }$ values for SULT1A1*1 and SULT1A1*2 with $\mathrm{T}_{3}$ as

Table 2 SULT1A $1 * 1$ and SULT1A1*2 kinetic data. All experiments were done based on the optimal conditions for SULT1A1 allozymes with $\mathrm{T}_{3}$ as the substrate. Each value represents the mean of 3 determinations from a representative experiment, except for the results with $T_{3}$, which represent the mean of three separate experiments, each done in triplicate

\begin{tabular}{|c|c|c|c|}
\hline \multirow[b]{3}{*}{ Substrate } & \multirow[b]{3}{*}{ Concentration range $(\mu \mathrm{M})$} & \multicolumn{2}{|l|}{$K_{\mathrm{m}}(\mu \mathrm{M})$} \\
\hline & & SULT1A1*1 & SULT1A1*2 \\
\hline & & & \\
\hline $\mathrm{T}_{3}$ & $1-256$ & $84 \cdot 4$ & $101 \cdot 3$ \\
\hline $\mathrm{T}_{4}$ & $30-600$ & 126 & 208 \\
\hline $\mathrm{rT}_{3}^{4}$ & $0 \cdot 1-100$ & $36 \cdot 1$ & $49 \cdot 8$ \\
\hline $3,3^{\prime}-\mathrm{T}_{2}$ & $0 \cdot 03-30$ & $0 \cdot 63$ & $0 \cdot 51$ \\
\hline $3,5-\mathrm{T}_{2}$ & $3-300$ & ND & ND \\
\hline
\end{tabular}

$\mathrm{ND}=$ not detected 


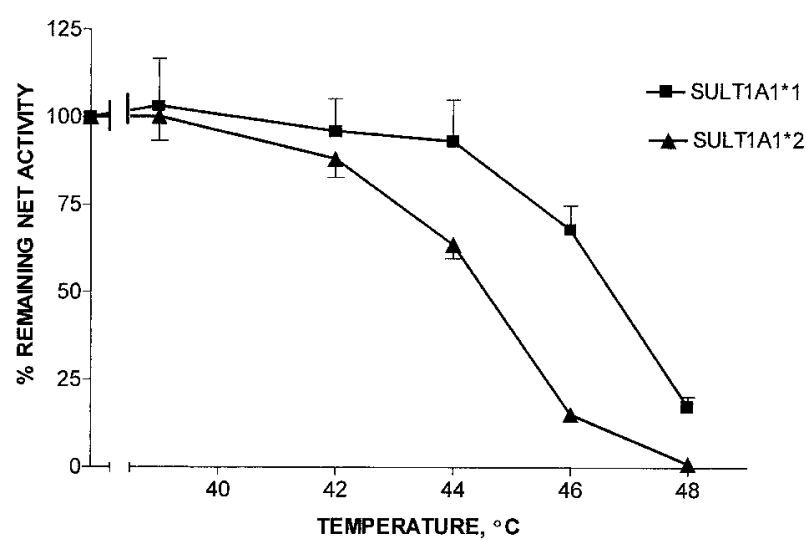

Figure 3 Thermal stability of SULT1A $1 * 1$ and SULT1A $1 * 2$ with $\mathrm{T}_{3}$ as the substrate. Allozyme activities were measured after preincubation for $15 \mathrm{~min}$ at the temperatures shown and expressed as a percentage of the net basal activity (unheated). Each point represents the mean \pm S.E.M. of 6 determinations.

the substrate were $2.45 \times 10^{-3} \pm 0.05 \times 10^{-3}$ (mean \pm S.E.M., $n=3$ experiments) and $0.82 \times 10^{-3} \pm 0.03 \times$ $10^{-3}$ (mean \pm S.E.M., $n=3$ experiments) Units/unit $\beta$ galactosidase activity respectively. Enzyme activities of SULT1A1*1 and SULT1A1*2 measured with $p$ nitrophenol as the substrate were $0.32 \pm 0.07$ and $0.08 \pm$ 0.02 Units/unit $\beta$-galactosidase activity respectively (mean \pm s.E.M., $n=3$ experiments). SULT1A1*1 activity was three times the SULT1A $1 * 2$ activity using $\mathrm{T}_{3}$ as the substrate $(P<0 \cdot 0001)$, and four times the SULT1A1*2 activity with $p$-nitrophenol as the substrate $(P<0 \cdot 03)$. These activity levels differed from the results reported with recombinant human liver SULT1A1*1 and SULT1A $1 * 2$, in which the two activities determined with $4 \mu \mathrm{M} p$-nitrophenol were essentially the same (Ozawa et al. 1999).

Thermal stability and inhibitor effects Further characterization of SULT1A1*1 and SULT1A1*2 was carried out with $\mathrm{T}_{3}$ at a final concentration of $150 \mu \mathrm{M}$. Thermal stability is an important biochemical property used for the characterization of human SULTs (Reiter et al. 1983, Anderson et al. 1988). SULT1A1*1 was more thermostable than SULT1A1*2 when assayed with $\mathrm{T}_{3}$ (Fig. 3). The 50\% inactivation temperatures for SULT1A $1 * 1$ and SULT1A $1 * 2$ were $46.9{ }^{\circ} \mathrm{C}$ and $44.5{ }^{\circ} \mathrm{C}$ respectively. This pattern was the same as those reported by other groups with $p$-nitrophenol as the substrate (Ozawa et al. 1999, Raftogianis et al. 1997, 1999). To further delineate differences between these allozymes, we investigated the effects of two known inhibitors of phenol SULTs, DCNP and $\mathrm{NaCl}$ (Young et al. 1988, Aksoy et al. 1994, Li \& Anderson 1999). SULT1A1*1 and SULT1A1*2 activities determined in the presence of varying concentrations of DCNP yielded $\mathrm{IC}_{50}$ values of $1.9 \mu \mathrm{M}$ and $1.7 \mu \mathrm{M}$ respectively. These results showed that the sensitivities to DCNP of

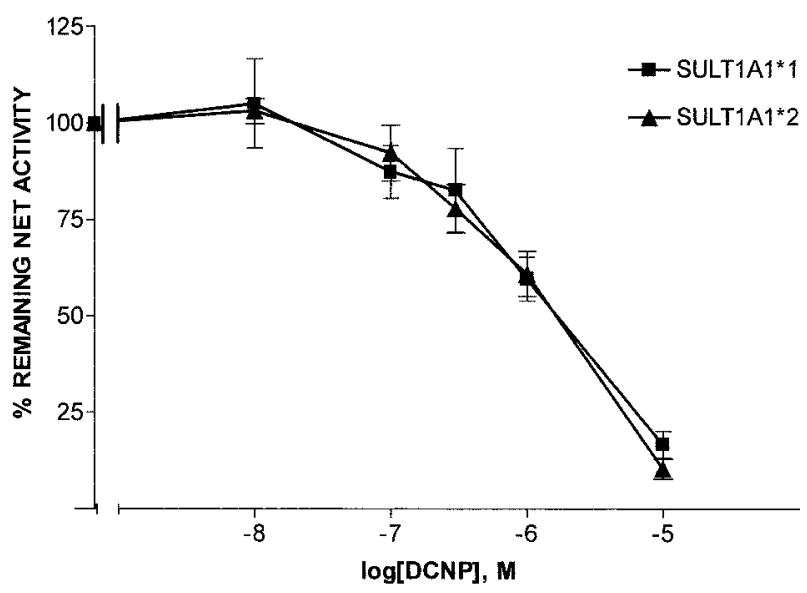

Figure 4 Effect of DCNP on SULT1A $1 * 1$ and SULT1A $1 * 2$ activities assayed with $T_{3}$. Allozyme activities were measured in the presence of various concentrations of DCNP and expressed as a percentage of the net basal activity (sample containing no DCNP). Each point represents the mean \pm S.E.M. of 6 to 12 determinations.

SULT1A1*1 and SULT1A1*2 activities were similar when assayed with $\mathrm{T}_{3}$ (Fig. 4). Using varying concentrations of $\mathrm{NaCl}$, the $\mathrm{IC}_{50}$ value for SULT1A1*1 was $224 \mathrm{mM}$ and for SULT1A1*2 was $305 \mathrm{mM}$. Thus, SULT1A1*1 activity was more sensitive to inhibition by $\mathrm{NaCl}$ than SULT1A1*2 when assayed with $\mathrm{T}_{3}$ (Fig. 5). Both were more resistant to $\mathrm{NaCl}$ inhibition when compared with the data obtained using p-nitrophenol (Clemens et al. 1996) and minoxdil (Kudlacek et al. 1999) as the substrates.

\section{SULT1A1*1 and SULT1A1*2 preferences for iodothyronines}

The relative abilities of SULT1A $1 * 1$ and SULT1A $1 * 2$ to use other iodothyronines as substrates were estimated by

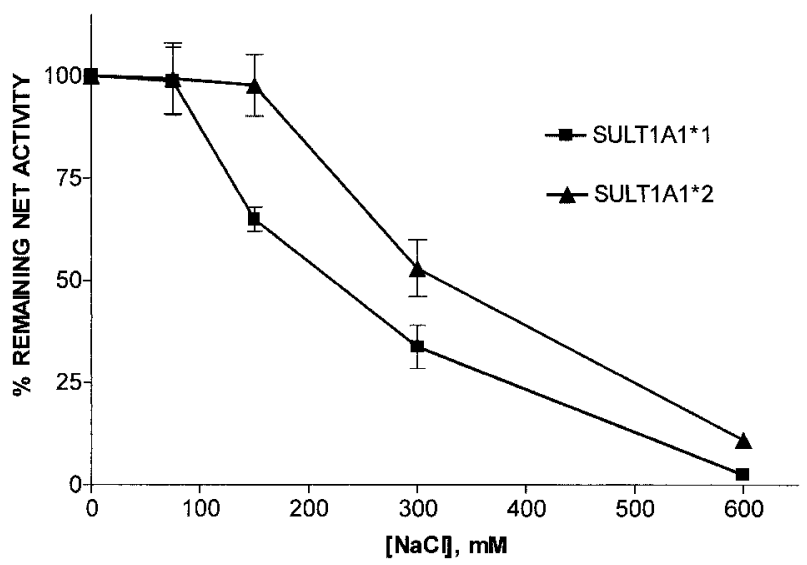

Figure 5 Effect of $\mathrm{NaCl}$ on SULT1A $1 * 1$ and SULT1A $1 * 2$ activities assayed with $\mathrm{T}_{3}$. Allozyme activities were measured in the presence of various concentrations of $\mathrm{NaCl}$ and expressed as a percentage of the net basal activity (sample containing no $\mathrm{NaCl}$ ). Each point represents the mean \pm S.E.M. of 6 determinations. 
$K_{\mathrm{m}}$ (Table 2). Assays were carried out under the optimal conditions established with $\mathrm{T}_{3}$ as the substrate. The preferences for the two allozymes were the same when estimated from the apparent $K_{\mathrm{m}}$ values. Both SULT1A1*1 and SULT1A1*2 were most active toward $3,3^{\prime}-\mathrm{T}_{2}$, followed by $\mathrm{rT}_{3}, \mathrm{~T}_{3}, \mathrm{~T}_{4}$, and $3,5-\mathrm{T}_{2}$ in order of decreasing specificity and activity.

\section{Conclusions}

There are at least six known human cytosolic SULTs (SULT1A1, SULT1A3, SULT1B1, SULT1C1, SULT1E1, SULT2A1) that contribute to the sulfation of thyroid hormones. We have demonstrated that human SULT1A1 allozymes (SULT1A1*1 and SULT1A1*2) catalyze the sulfation of $\mathrm{T}_{3}$ and three other iodothyronines. $\mathrm{T}_{3}$ enhances the resting metabolism of tissues through interaction with nuclear receptors. Sulfation and subsequent inactivation of $T_{3}$ by SULT1A1 allozymes might block the availability of $\mathrm{T}_{3}$ to bind the nuclear receptors. Thyroid hormones including $\mathrm{T}_{4}, \mathrm{rT}_{3}$, and 3,5- $\mathrm{T}_{2}$ mediate several extranuclear (nongenomic) actions at the cell membrane and cytoskeleton, such as the regulation of actin polymerization in glial cells to control cell surface availability of the type II $5^{\prime}$-deiodinase (Davis \& Davis 1996, Leonard \& Farwell 1997). In addition, 3,3'-T ${ }_{2}$ and $3,5-\mathrm{T}_{2}$ have been reported to act through nonnuclear pathways to enhance mitochondrial respiration and thus resting metabolism (Lanni et al. 1996, Moreno et al. 1997, Pillar \& Seitz 1997). Both SULT1A1*1 and SULT1A1*2 preferentially sulfoconjugated $3,3^{\prime}-\mathrm{T}_{2}$. Whether sulfation of $3,3^{\prime}-T_{2}$ might be a pathway for regulation of these nonnuclear actions is not clear.

Exogenous thyroid hormone preparations are among the most commonly prescribed medicines. Our results indicate that SULT1A1*1 and SULT1A1*2 present in the liver and gut may contribute to metabolism of thyroid hormones taken orally. Recombinant SULT1A1*1 and SULT1A1*2 had essentially the same substrate specificities and preferences for iodothyronines. However, their thermal stabilities and sensitivities to $\mathrm{NaCl}$ were different. It is not known whether the differences in biochemical properties of the SULT1A1 allozymes might alter individual responses to exogenous or endogenous thyroid hormones. Potential differences in thyroid hormone sulfation between individuals with predominant SULT1A1*1 versus SULT1A1*2 allozymes would be expected to be due to differences in catalytic activity rather than substrate specificity.

There are at least 7 allozymes of SULT1A1 and, undoubtedly, additional allozymes that have not yet been identified. We have tested the two most common SULT1A1 allozymes. Our work with COS-1 cell expressed SULT enzymes has demonstrated that these preparations reliably reflect the biochemical properties of the native human enzyme. Further studies of other SULT1A1 allozymes will be required to clarify potential differences in activity and specificity for thyroid hormones and their subsequent effects on thyroid hormone metabolism.

\section{Acknowledgements}

We thank Kathryn Hardin for her technical expertise and editorial assistance, ME McManus (Queensland, Australia) for the SULT1A1*2 cDNA, and Dr S-Y Wu (Long Beach, CA, USA) for the 3, $3^{\prime}-\mathrm{T}_{2}$. This work was presented in part at the ASBMB/ASPET/FPS/PSC 2000 Meeting in Boston, MA, June 4-8 2000, and was supported by the VA Medical Research Service.

\section{References}

Aksoy IA, Wood TC \& Weinshilboum RM 1994 Human liver estrogen sulfotransferase: identification by cDNA cloning and expression. Biochemical and Biophysical Research Communications 200 1621-1629.

Anderson RJ \& Liebentritt DK 1990 Human platelet thermostable phenol sulfotransferase: assay of frozen samples and correlation between frozen and fresh activities. Clinica Chimica Acta 189 221-230.

Anderson RJ, Jackson BL \& Liebentritt DK 1988 Human platelet thermostable phenol sulfotransferase from blacks and whites: biochemical properties and variations in thermal stability. Journal of Laboratory and Clinical Medicine 112 773-783.

Anderson RJ, Babbitt LL \& Liebentritt DK 1995 Human liver triiodothyronine sulfotransferase: copurification with phenol sulfotransferases. Thyroid 5 61-66.

Bradford MM 1976 A rapid and sensitive method for quantitation of microgram quantities of protein utilizing the principle of proteindye binding. Analytical Biochemistry 72 248-254.

Chopra IJ, Wu S-Y, Chua Teco GN \& Santini F 1992 A radioimmunoassay for measurement of 3,5,3'-triiodothyronine sulfate: studies in thyroidal and nonthyroidal diseases, pregnancy, and neonatal life. Journal of Clinical Endocrinology and Metabolism 75 189-194.

Clemens DL \& Carlson JO 1989 Regulated expression of the feline panleukopenia virus P38 promoter on extrachromosomal FPV/EBV chimeric plasmids. Journal of Virology 63 2737-2745.

Clemens D, Cole J, Kudlacek P, Halgard C \& Anderson R 1996 Human liver TS PST: cDNA cloning, bacterial expression and characterization. FASEB Journal 10 A284 (Abstract).

Coughtrie MWH, Gilissen RAHJ, Shek B, Strange RC, Fryer AA, Jones PW \& Bamber DE 1999 Phenol sulphotransferase SULT1A1 polymorphism: molecular diagnosis and allele frequencies in Caucasian and African populations. Biochemical Journal 337 45-49.

Davis PJ \& Davis FB 1996 Nongenomic actions of thyroid hormone. Thyroid 6 497-504.

Eisenthal R \& Cornish-Bowden A 1974 The direct linear plot. A new graphical procedure for estimating enzyme kinetic parameters. Biochemical Journal 139 715-720.

Fujita K, Nagata K, Ozawa S, Sasana H \& Yamazoe Y 1997 Molecular cloning and characterization of rat ST1B1 and human ST1B2 cDNAs, encoding thyroid hormone sulfotransferases. Journal of Biochemistry 122 1052-1061.

Glatt H, Engelke CEH, Pabel U, Teubner W, Jones AL, Coughtrie MWH, Andrae U, Falany CN \& Meinl W 2000 Sulfotransferases: genetics and role in toxicology. Toxicology Letters 112-113 341-348. 
Hwang S-R, Kohn AB \& Hook VYH 1995 Molecular cloning of an isoform of phenol sulfotransferase from human brain hippocampus. Biochemical and Biophysical Research Communications 207 701-707.

Ish-Horowicz D \& Burke JF 1981 Rapid and efficient cosmid cloning. Nucleic Acids Research 9 2989-2999.

Jones AL, Hagen M, Coughtrie MWH, Roberts RC \& Glatt H 1995 Human platelet phenolsulfotransferases: cDNA cloning, stable expression in V79 cells and identification of a novel allelic variant of the phenol-sulfating form. Biochemical and Biophysical Research Communications 208 855-862.

Kester MHA, Kaptein E, Roest TJ, Van Dijk CH, Tibboel D, Meinl W, Glatt H, Coughtrie MWH \& Visser TJJ 1999a Characterization of human iodothyronine sulfotransferases. Journal of Clinical Endocrinology and Metabolism 84 1357-1363.

Kester MHA, Van Dijk CH, Tibboel D, Hood AM, Rose NJM, Meinl W, Pabel U, Glatt H, Falany CH, Coughtrie MWH \& Visser TJ $1999 b$ Sulfation of thyroid hormone by estrogen sulfotransferase. Journal of Clinical Endocrinology and Metabolism 84 2577-2580.

Kudlacek P, Clemens DL \& Anderson RJ 1999 Human liver recombinant thermostable phenol sulfotransferase (SULT1A1) allozymes characterized with minoxidil. FASEB Journal 99 A1013 (Abstract).

Lanni A, Moreno M, Lombardi A \& Goglia F 1996 Calorigenic effect of diiodothyronines in the rat. Journal of Physiology 494 831-837.

Leonard JL \& Farwell AP 1997 Thyroid hormone-regulated actin polymerization in brain. Thyroid 7 147-151.

Li X-Y \& Anderson RJ 1999 Sulfation of iodothyronines by recombinant human liver steroid sulfotransferases. Biochemical and Biophysical Research Communications 263 632-639.

Li X-Y, Clemens DL \& Anderson RJ 2000 Sulfation of iodothyronines by human sulfotransferase 1C1 (SULT1C1). Biochemical Pharmacology 60 1713-1716.

LoPresti JS \& Nicoloff JT 1994 3,5,3'-Triiodothyronine $\left(T_{3}\right)$ sulfate: a major metabolite in $\mathrm{T}_{3}$ metabolism in man. Journal of Clinical Endocrinology and Metabolism 78 688-692.

Moreno M, Lanni A, Lombardi A \& Goglia F 1997 How the thyroid controls metabolism in the rat: different roles for triiodothyronine and diiodothyronines. Journal of Physiology 505 529-538.

Ozawa S, Nagata K, Shimada M, Ueda M, Tsuzuki T, Yamazoe Y \& Kato R 1995 Primary structures and properties of two related forms of aryl sulfotransferase in human liver. Pharmacogenetics $\mathbf{5}$ S135-S140.

Ozawa S, Shimizu M, Katoh T, Miyajima A, Ohno Y, Matsumoto Y, Fukuoka M, Tang Y-M, Lang NP \& Kadlubar FF 1999 Sulfatingactivity and stability of cDNA-expressed allozymes of human phenol sulfotransferase, ST1A3*1 (213 Arg) and ST1A3*2 (213 His), both of which exist in Japanese as well as Caucasians. Journal of Biochemistry 126 271-277.

Pillar TM \& Seitz HJ 1997 Thyroid hormone and gene expression in the regulation of mitochondrial respiratory function. European Journal of Endocrinology 136 231-239.

Price RA, Spielman RS, Lucena AL, Van Loon JA, Maidak BL \& Weinshilboum RM 1989 Genetic polymorphism for human platelet thermostable phenol sulfotransferase (TS PST) activity. Genetics $\mathbf{1 2 2}$ 905-914.

Raftogianis RB, Wood TC, Otterness DM, Van Loon JA \& Weinshilboum RM 1997 Phenol sulfotransferase pharmacogenetics in humans: association of common SULT1A1 alleles with TS PST phenotype. Biochemical and Biophysical Research Communications 239 298-304.

Raftogianis RB, Wood TC \& Weinshilboum RM 1999 Human phenol sulfotransferases SULT1A2 and SULT1A1: genetic polymorphisms, allozyme properties, and human liver genotypephenotype correlations. Biochemical Pharmacology 58 605-616.

Reiter C, Mwaluko G, Dunnette J, Van Loon J \& Weinshilboum RM 1983 Thermolabile and thermostable human platelet phenol sulfotransferase: substrate specificity and physical separation. Naunyn-Schmiedeberg's Archives of Pharmacology 324 140-147.

Sanger F, Nicklen S \& Coulson AR 1977 DNA sequencing with chain-terminating inhibitors. PNAS 74 5463-5467.

Van Loon JA \& Weinshilboum RM 1984 Human platelet phenol sulfotransferase: familial variations in the thermal stability of the TS form. Biochemical Genetics 22 997-1014.

Visser TJ, Kaptein E, Glatt H, Bartsch I, Hagen M \& Coughtrie MWH 1996 Characterization of thyroid hormone sulfotransferases. Thyroid 6 (Suppl 1) S22 (Abstract).

Wang J, Falany JL \& Falany CN 1998 Expression and characterization of a novel thyroid hormone-sulfating form of cytosolic sulfotransferase from human liver. Molecular Pharmacology 53 274-282.

Wilborn TW, Comer KA, Dooley TP, Reardon IM, Heinrikson RL \& Falany CN 1993 Sequence analysis and expression of the cDNA for the phenol sulfating form of human liver phenol sulfotransferase. Molecular Pharmacology 43 70-77.

Young WF, Gorman CA \& Weinshilboum RM 1988 Triiodothyronine: a substrate for the thermostable and thermolabile forms of human phenol sulfotransferase. Endocrinology 122 1816-1824.

Zhu X-Y, Veronese ME, Bernard CCA, Sansom LN \& McManus ME 1993 Identification of two human brain aryl sulfotransferase cDNAs. Biochemical and Biophysical Research Communications 195 120-127.

Received 19 May 2001

Accepted 21 August 2001 